\title{
HEREDITARY NONPOLYPOSIS COLORECTAL CANCER IDENTIFICATION AND SURVEILLANCE OF HIGH-RISK FAMILIES
}

\author{
Roberta Vasconcelos e Silva ${ }^{1}$, Bernardo Garicochea ${ }^{2,3}$, Guilherme Cotti ${ }^{1}$, Isabel \\ Cristina Maranho', and Raul Cutait ${ }^{1,2}$
}

\begin{abstract}
Silva RV e, Garicochea B, Cotti G, Maranho IC, Cutait R. Hereditary nonpolyposis colorectal cancer identification and surveillance of high-risk families. Clinics. 2005;60(3):251-6.
\end{abstract}

Hereditary nonpolyposis colorectal cancer is an autosomal dominant condition caused by highly penetrant gene mutations. It is characterized by increased susceptibility for a specific group of cancer, mainly colorectal cancer. The syndrome originates from the inheritance of mutations in DNA mismatch repair genes. The most commonly affected genes in hereditary nonpolyposis colorectal cancer are hMLH1 and hMSH2. Their deficient expression renders the cell susceptible to the accumulation of many molecular defects, a condition which can be evaluated by the instability in sections of base repeats in the genoma known as microsatellite instability. The molecular detection of hereditary nonpolyposis colorectal cancer is possible in most of the highly suspicious cases. Genetic tests for hereditary nonpolyposis colorectal cancer also allow characterization of the individual that bears the mutation within a family. The high cost and restricted availability of these tests hamper their use for every person presenting colorectal cancer. Due to this fact, some clinical criteria have been developed by a hereditary nonpolyposis colorectal cancer international organization to select families with a high probability of carrying the mutation. Once families at risk are identified, they are encouraged to join a screening program that aims at early detection of hereditary nonpolyposis colorectal cancer-related cancers, increasing the possibility of its prevention and early detection.

KEYWORDS: Hereditary nonpolyposis colorectal cancer. Follow-up. Screening. Mismatch repair gene. Microsatellite instability.

Hereditary nonpolyposis colorectal cancer (HNPCC), also known as the Lynch syndrome, is characterized by increased susceptibility to colorectal neoplasms and secondarily to stomach, endometrial, ovarian, hepatobiliary, and renal cancers. ${ }^{1,2}$ Colorectal cancers (CRC) occur earlier (about 45 years of age), compared to subjects with sporadic CRC (starting at 60 years of age). ${ }^{3,4}$ It is a highly penetrant dominant autosomal condition, ${ }^{3,4}$ and once the syndrome is diagnosed, these subjects have a $70 \%$ to $80 \%$ chance of

Faculty of Medicine ${ }^{1}$, University of São Paulo - São Paulo/SP, Brazil. Institute of Oncology ${ }^{2}$, Sírio Libanês Hospital - São Paulo/SP, Brazil. Oncology Service ${ }^{3}$, Faculty of Medicine, Pontifical Catholic University of Rio Grande do Sul - Porto Alegre/RS, Brazil.

Email: bgarico@uol.com.br

Received for publication on September 27, 2004.

Accepted for publication on February 22, 2005. developing CRC and a 39\% chanceof evolving endometrial cancer up to 80 years of age. ${ }^{3-5}$

Hereditary nonpolyposis colorectal cancer is of considerable epidemiological importance. It is estimated that this condition occurs in about $5 \%$ to $10 \%$ of patients with CRC. ${ }^{6,7}$ If all families with this mutation were included, the number of affected subjects would be considerably higher.

Although the genetic and hereditary bases are relatively well defined, the clinical manifestations of HNPCC are not specific to this disease, and diagnosis based solely on family history of cancer is possible only in a minority of cases.

Nevertheless, CRC in patients with HNPCC presents some traits that can help to identify high-risk subjects. For example, tumor location tends to be proximal ${ }^{4,8}$ and presents an abnormally high frequency of mucinous or signet cells. Moreover, the adenoma-carcinoma sequence ap- 
pears to be accelerated, ${ }^{9,10,11}$ and there is a strong tendency for development of synchronic and metachronic lesions. ${ }^{4,5}$

The genetic hallmark of HNPCC is the occurrence of mutations in a set of genes responsible for a specific type of DNA repair, called the mismatch repair (MMR) system. It is not rare to observe some errors during base pair arrangements that take place during the process of DNA replication. This phenomenon does not usually result in cell damage because of the MMR system, which comprises a unit of at least 6 proteins, encoded by the following genes: MLH1, MSH2, MSH3, MSH6, PMS1, and PMS2. The proteins of the MMR system act in a coordinated manner to identify minor reading errors on the replicated DNA strand, proceeding to the elimination of damaged DNA and substitution of a sequence that is perfectly paired with the mother strand. ${ }^{9,12,14}$ Most of HNPCC cases are due to mutations that inactivate the MSH2 and MLH1 genes, the former being responsible for $50 \%$, the latter for $30 \%$ of the cases. ${ }^{12,13}$ Cases of HNPCC involving other genes of the MMR complex have been described, but are much less common. Great interest has been aroused by studies which observed that mutations of the MSH6 gene increase susceptibility to endometrial carcinoma in families with a history of HNPCC. ${ }^{9,12}$

Microsatellites, defined as short repeated base sequences present in non-codifying regions of DNA and whose function is as yet unknown, are one of the DNA regions most affected by replication error. In the presence of mutated MMR genes, the microsatellite copies of the daughter cells may not be identical to the mother cells. This variation in the extension of these repetitive sequences compared to the normal DNA ${ }^{12,14,15}$ results in the so-called microsatellite instability, or replication error. Studies show that about $90 \%$ of cancers due to a mutation in hMLH1 and hMSH2 display microsatellite instability. ${ }^{14}$

\section{CLINICAL DIAGNOSIS}

Currently, diagnosis of HNPCC is made based predominantly on a detailed family history of cancer according to criteria established by the International Collaborative Group on Hereditary Nonpolyposis Colorectal Cancer (ICG-HNPCC) known as the Amsterdam Criteria I and $\mathrm{II}^{13,16}$ (Table 1). They are highly specific criteria that are simple to apply.

Nonetheless, because they are very restrictive, $, 3,5,17$ a large number of affected families are excluded (i.e., small families or those whose history is difficult to obtain). Additionally, the Amsterdam Criteria help to define affected families, but they do not allow identification of affected individuals within an HNPCC family.

Recently, genetic tests that can identify HNPCC carriers have become available, which permit the diagnosis of
Table 1 - Amsterdam criteria I and II $^{16}$.

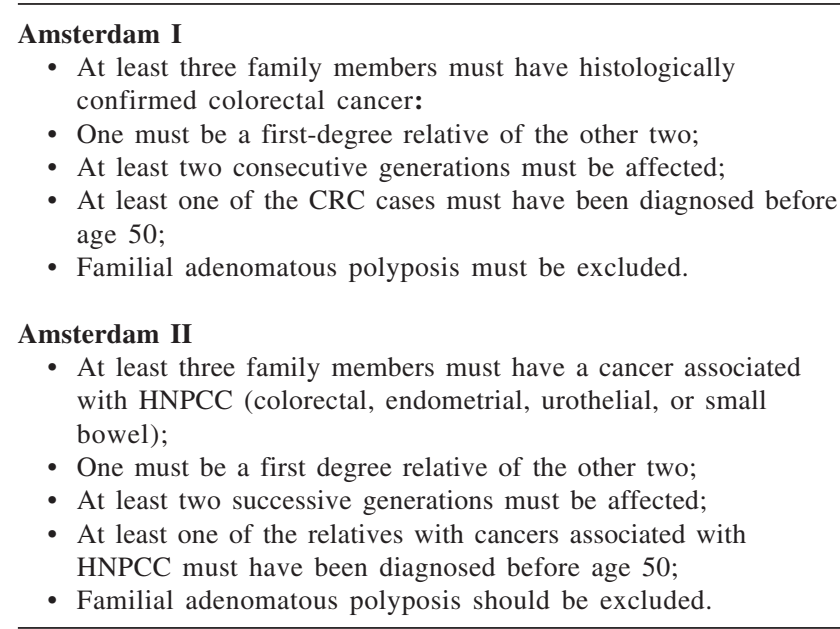

the syndrome regardless of a family history. However, this type of test can not be applied in all cases of CRC because of its high cost and paucity of qualified laboratories capable of performing it. In order to aim these sophisticated tests towards a selected group of subjects with higher probability of HNPCC, new criteria were developed, termed the Bethesda guidelines. ${ }^{17,18}$ The objective of these guidelines was not the clinical diagnosis of the syndrome, but the identification of those patients who should undergo more detailed laboratory investigation (Table 2).

Table 2 - Bethesda criteria ${ }^{17}$.

1. Individuals with cancer that belong to families that fulfill the Amsterdam Criteria;

2. Individuals with two or more cancers related to HNPCC, including synchronic and metachronic CRC and related* extracolonic cancers;

3. Individuals with $\mathrm{CRC}$ and a first-degree family member with $\mathrm{CRC}$ and/or extracolic cancer related to HNPCC and/or colorectal adenoma; one of the cancers diagnosed before age 45 and the adenoma before age 40 ;

4. Individuals with $\mathrm{CRC}$ or endometrial carcinoma diagnosed before age $45^{* *}$;

5. Individuals with right colon $\mathrm{CRC}$ with undifferentiated histopathology (solid/cribriform) diagnosed before age $45^{* *}$;

6. Individuals with $\mathrm{CRC}$ with signet cell features diagnosed before age $45+++$;

7. Individuals with adenomas diagnosed before age 40 .

*Endometrium, ovarian, stomach, hepatobiliary, small bowel, transitional cell carcinoma of the pelvis or ureter.

**Solid/cribriform defined as little or undifferentiated carcinoma composed of irregular leaflets and solid areas of large eosinophilic cells containing small spaces similar to glands.

$* * *$ Composed of over $50 \%$ of signet cells.

\section{LABORATORY DIAGNOSIS}

The establishment of a genetic diagnosis of HNPCC has filled the gaps left by the syndrome's investigative clinical 
criteria. Currently, the genetic tests enable us to not only accurately diagnose the major group of families with unconfirmed history, but also to investigate the presence or absence of mutations in each family.

The main tests now available for investigating the syndrome are:

- Microsatellite instability test (MSI) ${ }^{14,19}$ screening for HNPCC - Accomplished in paraffin-block tumor specimens, they require microdissection of tumor tissue and adjacent normal tissue by an experienced pathologist, followed by extraction of DNA from both samples and performance of polymerase chain reaction (PCR) in different microsatellite regions. The test comprehends a panel of markers proposed by the International Collaborative Group on HNPCC (the microsatellite regions suggested by the panel are: BAT25, BAT26, DS123, D5S346, and D17S250), that permit classification of rising instability (MSI-H), when $30 \%$ or more markers are unstable, low (MSI-L) when instability is up to $30 \%$, or absent (MSS), when there is no instability. Tumors associated with HNPCC almost always demonstrate a high degree of instability. ${ }^{20}$

- Immunohistochemistry for proteins of DNA repair genes (1H) - Normal tissues express large amounts of MLH1 and $\mathrm{MSH} 2$ proteins in the nucleus. Interruption of the protein by mutations results in reduction in their nuclear levels, and $50 \%$ of cases of HNPCC display this reduction or absence of $1 \mathrm{H}$ in paraffin specimens. ${ }^{14,21}$ Therefore, similar to MS1, this test is also performed as a screening test from tumor specimens; that is, it can only be performed in probands, and not in their healthy relatives.

- DNA sequencing ${ }^{14,22}$ — This is the gold standard for detection of mutations. It consists of comparing each pair of bases of a gene, or part of it, in blood samples to the corresponding region of normal DNA. Despite its great accuracy, it has a sensitivity of $70 \%,{ }^{20,22}$ even when performed in highly selected subjects with clinical diagnosis of HNPCC based on the Amsterdam criteria. Additionally, DNA sequencing remains an expensive and time consuming technique. Even so, once a mutation is detected in a proband, the other relatives can be tested at a lower cost and within a shorter time period, since the study can then be performed in only the mutated region.

Despite the genetic development observed in HNPCC diagnosis, there are cases in which the diagnosis remains difficult, due to the large variety of family histories and controversial questions that may face the physician. In addition, the laboratory methods still present considerably high rates of false-positive and false-negative results.

An algorithm for the management of an affected individual is proposed in Figure 1. Initially immunohistochemical tests are routinely performed because of their simplic-

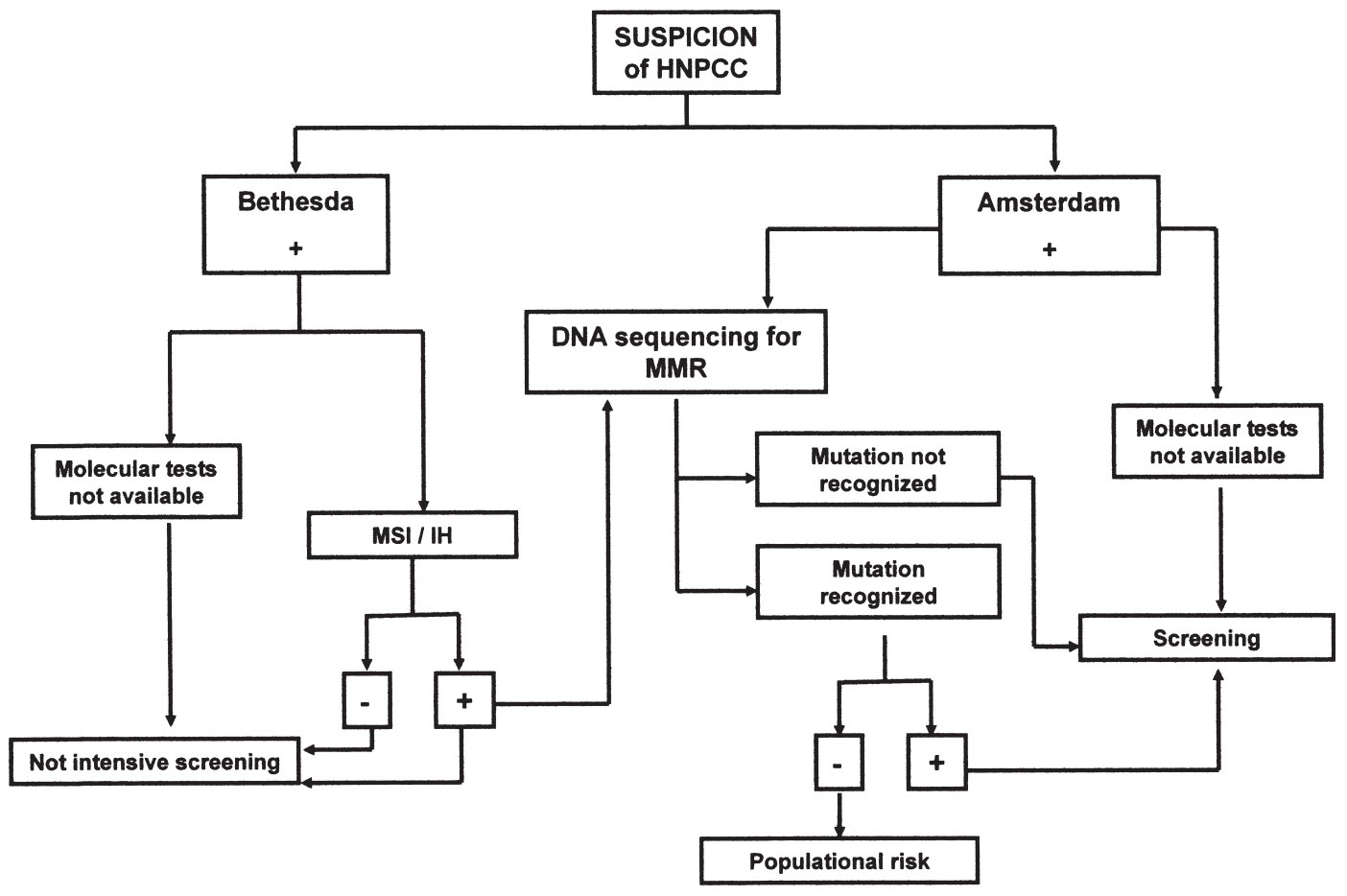

Figure 1 - Algorithm for Hereditary nonpolyposis colorectal cancer (HNPCC) diagnosis ${ }^{20}$. 
ity and lower cost. If the result is negative or if these tests are not available, the MSI is performed. DNA sequencing is reserved for cases with a positive immunohistochemical or MSI test (Table 3).

Table 3 - Guidelines recommended by ICG-Hereditary nonpolyposis colorectal cancer for preventive examinations and early diagnosis of colorectal cancer and extracolic tumors $^{25}$.

\begin{tabular}{llll}
\hline Organ & Examination & Start (Age) & Frequency \\
\hline Colon \& Rectum & colonoscopy - & $20-25$ & Each 2 years \\
\hline Endometrium & $\begin{array}{l}\text { gynecological } \\
\text { examination, } \\
\text { endovaginal } \\
\text { ultrasonography }\end{array}$ & $30-35$ & $1-2$ years \\
\hline Ovaries & $\begin{array}{l}\text { Ultrasonography } \\
\text { of pelvis, CA 125 }\end{array}$ & \\
\hline Urinary tract & $\begin{array}{l}\text { ultrasonography, } \\
\text { urine I }\end{array}$ & 1-2 years \\
\hline Stomach & gastroendoscopy & $30-35$ & 2-3 years \\
\hline
\end{tabular}

\section{SCREENING OF AFFECTED FAMILIES}

Families that fulfill the Amsterdam criteria or at least 1 of the Bethesda guidelines criteria with MSI-H, besides those known to be carriers of mutations in 1 of the repair genes related to HNPCC, should undergo screening programs. When the MSI test is not available, it is also advisable to screen families that fulfill at least 2 of the Bethesda criteria, especially those related to probands diagnosed with cancer at an early age. In families undergoing genetic investigation, only members known to be carriers of mutations need to be screened. ${ }^{20}$
Even in those familes that usually do not display extracolic tumors, all the organs commonly affected by HNPCC should be analyzed periodically. The beginning of the examinations is usually defined as 10 years before the age of tumor diagnosis in the family.

The ICG-HNPCC (International Collaborative Group on HNPCC) recommends colonoscopies annually or every 2 years starting at age 25 (or every 5 years before the age of appearance of $\mathrm{CRC}$ in the youngest affected individual in the family) for first-degree relatives of HNPCC carriers. Additionally, annual screening for endometrial cancer is recommended for women (transvaginal ultrasonography or endometrial aspiration) starting at 30 years of age (Table 3 ).

\section{CONCLUSION}

Identifying individuals and families at high risk of developing diseases associated with high morbidity and mortality is a very important goal in public health. In situations where the early detection of the disease is possible, as in the case of hereditary cancer syndromes such as HNPCC, the mortality and incapacitation levels can be significally reduced with the implementation of the right screening strategies. In addition, this policy results in lower costs when compared to costs of the treatment of advanced colorectal cancer.

The judicious evaluation of the family history of patients with colorectal cancer allows the correct use of more specific and sophisticated tests that can improve management of families with histories of HNPCC. Therefore, the efforts of health professionals in investigating and motivating families to join screening programs are extremely important.

\section{RESUMO}

Silva RV e, Garicochea B, Cotti G, Maranho IC, Cutait R. Câncer colo-retal hereditário não polipose - Diagnóstico e surgimento de famílias de alto risco. Clinics. 2005;60(3):251-6.

O câncer colo-retal hereditário não polipose é uma síndrome genética caracterizada por uma susceptilidade aumentada para certos tipos específicos de câncer, especialmente o câncer colo-retal. Ao nível molecular, a síndrome caracteriza- se pela herança autossômica dominante de mutações em genes envolvidos em um mecanismo de reparo do DNA dirigido para defeitos em trocas, ganhos ou perdas de um número de pequeno de bases, chamado de sistema de reparo de erros de pareamento. Os genes mais comumente afetados em câncer colo-retal hereditário não polipose são hMLH1 e hMSH2, e sua inativação destina a célula portadora à acumulação de mutações, uma condição conhecida como fenótipo de erro de replicação. Estas mutações múltiplas 
serão transmitidas e amplificadas em células-filhas e sua identificação pode ser feita por meio da identificação de distúrbios em sequiências repetidas de DNA chamadas de microssatélites. Células portadoras de defeitos deste tipo em seus microssatélites apresentam um fenótipo denominado de instabilidade de microssatélites (também denominado fenótipo MSI). Por meio da detecção destes defeitos genéticos é possível, presentemente, a realização de um diagnóstico preciso de câncer colo-retal hereditário não polipose, permitindo a atuação preventiva em portadores da síndrome que ainda não desenvolveram câncer. Contudo, limitações financeiras e de acesso aos exames inviabilizam sua realização em todos os indivíduos que apresentam câncer colo-retal. Por isso, foram estabelecidos pela comunidade internacional alguns critérios que selecionam as famílias com alta probabilidade de possuírem a mutação e que, portanto, podem beneficiar-se com estes exames. Este artigo procura abordar as estratégias recomendadas para identificação de casos de alto risco de câncer colo-retal hereditário não polipose, os testes genéticos disponíveis para estes casos e as recomendações para prevenção e seguimento destas famílias.

UNITERMOS: Câncer colo-retal hereditário não polipose. Seguimento. Rastreamento. Sistema de reparo de erros de pareamento. Instabilidade de microssatélites.

\section{REFERENCES}

1. Hampel H, Peltomaki P. Hereditary colorectal cancer: risk assessment and management. Clin Genet. 2000;58(2):89-97.

2. Lisa A. Heritable colorectal cancer syndromes: recognition and preventive management. Gastroenterol Clin North Am. 2002;31(4):1107-31.

3. Chung DC, Rustgi AK. Nonpolyposis colorectal cancer syndrome: genetics and clinical implications. Ann Intern Med. $2003 ; 138(7): 560-70$

4. Lynch HT, Smyrk T. Hereditary nonpolyposis colorectal cancer (Lynch syndrome). An updated review. Cancer. 1996;78(6):114967.

5. Terdiman JP, Conrad PG, Sleisenger MH. Genetic testing in hereditary colorectal cancer: indications and procedures. Am J Gastroenterol. 1999;94(9):2344-56.

6. Mecklin J. Frequency of hereditary colorectal carcinoma. Gastroenterology. 1987;93(5):1021-5.

7. Presciuttini S, Strigini P. Genetic epidemiology of the colorectal cancer. Tumori. 1996;82(2):107-13.

8. Hadley DW, Jenkins J, Dimond E, Nakahara K, Grogan L, Liewehr DJ, et al. Genetic counseling and testing in families with hereditary nonpolyposis colorectal cancer. Arch Intern Med. 2003;163(5):573-82.

9. Lynch HT, de la Chapelle A. Hereditary colorectal cancer. N Engl J Med. 2003;348(10):919-32.

10. Lynch HT. Is there a role for prophylactic subtotal colectomy among hereditary nonpolyposis colorectal cancer germline mutation carriers?. Dis Colon Rectum. 1996;39(1):109-10.
11. Lynch HT, Watson P, Shaw TG, Lynch JF, Harty AE, Franklin BA, et al. Clinical impact of molecular genetic diagnosis, genetic counseling, and management of hereditary cancer. Part II: Hereditary nonpolyposis colorectal carcinoma as a model. Cancer. 1999;86(11 Supp1):2457-63.

12. Chung DC, Rustgi AK. DNA mismatch repair and cancer. Gastroenterology. 1995;109(5):1685-99.

13. Samowitz WS, Curtin K, Lin HH, Robertson MA, Schaffer D, Nichols M, et al. The colon cancer burden of genetically defined hereditary nonpolyposis colon cancer. Gastroenterology. $2001 ; .121(4): 830-8$

14. Solomon $\mathrm{CH}$, Pho LN, Burt RW. Current status of genetic testing for colorectal cancer susceptibility. Oncology. 2002;16(2):16171; discussion 176, 179-80

15. Cutait R, Cotti G, Garicochea B, Muraro C, Carvalho F, Leite K, et al. Instabilidade de microssatélites em portadores de câncer coloretal. Rev Bras Coloproct. 2002;22(4):225-32.

16. Vasen HF, Watson P, Mecklin JP, Lynch HT. New clinical criteria for hereditary nonpolyposis colorectal cancer (HNPCC, Lynch syndrome) proposed by the International Collaborative group on HNPCC. Gastroenterology. 1999;116(6):1453-6.

17. Rodriguez-Bigas MA, Boland CR, Hamilton SR, Henson DE, Jass JR, Khan PM, et al. A National Cancer Institute Workshop on Hereditary Nonpolyposis Colorectal Cancer Syndrome: meeting highlights and Bethesda guidelines. J Natl Cancer Inst. 1997;89(23):1758-62.

18. Carvalho F, Cutait R, Muraro C, Borges J, Garicochea B, Leite K, et al. Prospective analysis of colon cancer bearing at least one Bethesda criterium-high frequency of microssatellite instability. Rev Bras Coloproct. 2000;20(suppl 1):225. 
19. Aaltonen LA, Salovaara R, Kristo P, Canzian F, Hemminki A, Peltomaki $\mathrm{P}$, et al. Incidence of hereditary nonpolyposis colorectal cancer and the feasibility of molecular screening for the disease. $\mathrm{N}$ Engl J Med. 1998;338(21):1481-7.

20. Cutait R, Garicochea B, Cotti G. HNPCC-Câncer Colorretal Hereditário Não Polipose. 2004. Ernesto Reichmman.

21. Cutait R, Leite K, Câmara-Lopes L, Cotti G, Garicochea B. Immunohistochemistry for MLH1 and MSH2-a new tool to identify HNPCC family members. Rev Bras Coloproct. 2000;20(suppl 1):224.

22. Hors C, Cutait R, Sarroca C, Cotti G, Garicochea B. Estratégia para diagnóstico molecular em famílias portadoras de HNPCC. Rev Bras Coloproct. 2001;21(suppl 1):36.
23. Smith RA, Cokkinides V, Eyre HJ; American Cancer Society. American Cancer Society guidelines for the early detection of cancer, 2003. CA Cancer J Clin. 2003;53(1):27-43.

24. Winawer SJ, Fletcher RH, Miller L, Godlee F, Stolar MH, Mulrow $\mathrm{CD}$, et al. Colorectal cancer screening and surveillance: clinical guidelines and rationale-Update based on new evidence. Gastroenterology. 2003;124(2):544-60.

25. ICG-HNPCC. Guidelines for management recommended by ICGHNPCC. 2004.www.nfdht.nl. 